“Film 一枚の観察に於ては, 観察者の経験が大きな 役割をするが，立体視によって或程度判断の個人差は 除汃れ得ると思える、撮影時の条件及び現像時の条件 芷慎重侤慮して出来上った二枚の film 同様ないい Contrast 莡持って居れば, 立体写真の観察により得ら れる結果は期待すべきものがある。最近閜題になり， 又予後の半!定に大きな影響のある結核尰芑其の漂度, 気管支の状況により，再燃の危険を或程度予知可能で あり, 空洞周国の滲出性陰影の状態, 拉ぶりにより, 手術簕囲の決定に役立ち, Tomography の補助により 磪固たる結果を予测出来るであろう。立体写真は前述 の条件の改善及び気管支造影像或は斜位時の撮影によ り, 陰影及び予後の判定に欠くべからざるものになり 得るものと考えられる”。以上は横山医博の御意見で あるが普通のX線写真で見出されなかった病集や陰影 が立体像ででは発見出来るととが屢々ある、文梁度が 客観的に測定されるので, 手術虎する場合や, 陰影変 化の位置が臨休的に重大な意義を有する場合には大き な助けとなる。

\section{4) 結言}

本装置では平面像で不明瞭な内部の微細な変化を容 易に捕えるここが出来た，且つ深度の測定は Tomo- graphy と共に客観的な知識として㟝断に役立つ。今 後 film change $と$ tube shift と足聯動し短時間に撮 影出来れで特に心膊聯動同期装置と組合せるととが出 来れば一層の効果が期待される. 尚現在, 此研究の続 きとして同時撮影法や搪大立体写真法力略々成果觉收 めたので次の機会に発表する積りである。

最後に以上の研究に当り終始多大の援助を与兄られ た日立製作所戸塚病院長横山功喜医博並に器械の試作 に㙝力居いただいた方々に対しととに深謝の意芷表す る.

\section{交献}

1) 岡䗁文次 : 立体写真, 科学写真便覽応用篇 p. 688 . 丸善（昭27）。

2) a) J. T. Case : A. J. of R. 9, 113 (1918).

b) E. W. Caldwell : A. J. of R. 9, 554(1918).

c) Joseph, Sauro: A.J. of R. 4, 824 (1953).

d) Military Roentgenology p. 362.

e）牛田信義：日医放 2, 102 (1941).

3) H.F. Kurtz and E. Bridge : A.J. of R. 18, 370 (1927).

4）a）志賀達雄：日レ誌，16，185 (1938).

b）小泉䔫太：日放技誌，9－2，68(1953).

\title{
断層像改善の一考察
}

\author{
結核子防会保生園 \\ 絴川高美
}

(論交受付 昭和30年11月 5 日)

\section{A METHOD OF IMPROVING THE TOMOGRAPHIC IMAGE}

\author{
By Takami Tsunakawa \\ Tuberculosis Prophylactic \\ Cooperation, Hoseien.
}

(Article received: Nor. 5, 1955)

\section{Summary}

We often find the diseased part of the tuberculosis at the back of the upper part of the lung.

So that, in tomography, it is necessary to remain the shadow of the diseased part and to take off the shadow of the costal bow (which is in the closely neighbourhood of the diseased part and has large contrast).

Here is described the new method of decreasing the contrast between these shadows by using stroboscopic method. 


\section{緒言}

結核病坚は肺上野の背部に好発するのでその断層写 真では，病巣の焱い影を残してそのすぐ隣に在るコン トラストの強い肋骨陰影を消さればならない，是は仲 々六カ敷いととで, 肋骨の影が幽霊のしっぽの様价 んやりと残って居る写真を霓々見受ける。ひどいのに なると背部加ら $5 \mathrm{~cm}, 6 \mathrm{~cm}$ と言う様な写真にも肋骨 がうっすらと残って居るてとが在る。こう言う写真が 出来ると医師はもっと薄く切って與れと言うし，技師 は $60^{\circ}$ ですから是以上薄くはなりませんと言う。こん な場合要するに肋骨の影が消えさえすれば解決するの であるから，肋骨の写る原因を調べてそれを取り去れ ばよい。てう言う時にはストロボグラフを造って見る のも一つの方法である。

\section{ストロボグラフに依る検査}

断層寝台の上に取枠を置き，フイルムから $10 \mathrm{~cm}$ 離

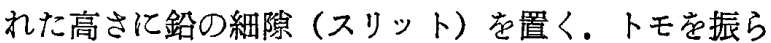
せて露出し 現像すると第 1 図C の様なストロボグラ フが出来る。

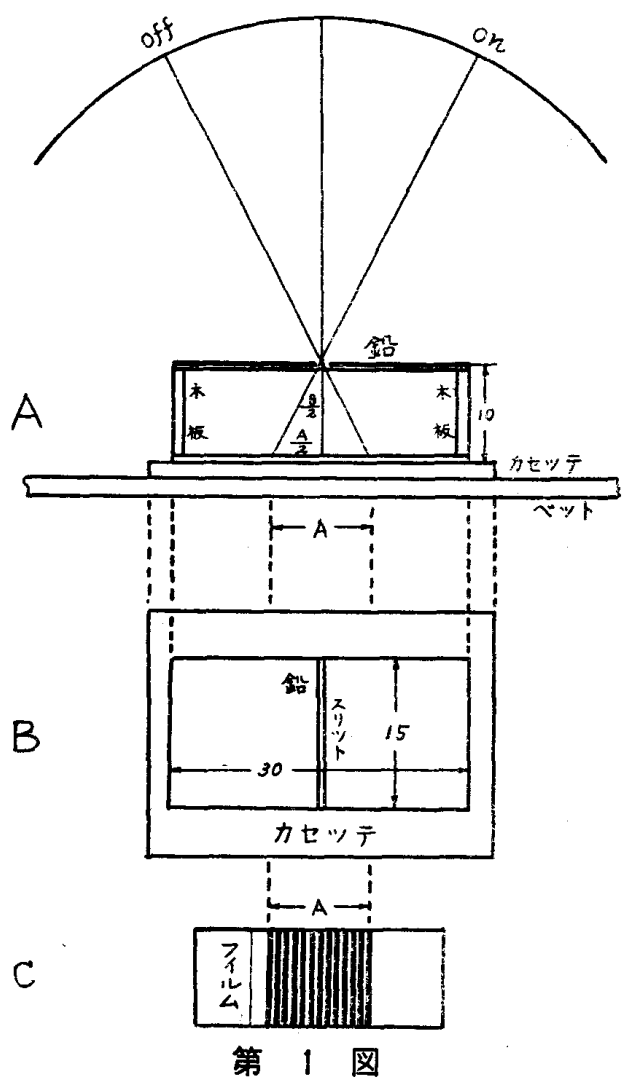

てのやり方を少し詳しく説明すると，

1. 材 料 ベニヤ板 $30 \mathrm{~cm} \times 150 \mathrm{~cm}$ のの 2 枚 3 分厚杉板 $(10 \mathrm{~cm}$ 一ベニヤ板の厚みの 2 倍 $) \times 15 \mathrm{~cm}$

のもの 2 枚.

$0.5 \mathrm{~mm}$ 鉊板 $30 \mathrm{~cm} \times 15 \mathrm{~cm}$ のもの 1 枚, 乙の鉛板 は四つ切取枠のバックからはぎ取ればよい。

2.工作. 第 1 図 A はスリットカメラの側面図. Bは上から見た図であるから是を参照して高さ $10 \mathrm{~cm}$ の木枠を造る，次に鉛板を鋭利なカッターで二等分し て $15 \mathrm{~cm} \times 15 \mathrm{~cm} の も の 2$ 枚とし, その断端を $1 \mathrm{~mm}$ 位 離してべニヤ板の上に載せスリットにする。

3. 第 1 図の様にセットし，断面をスリットの高さ にする，X線管を引きそれが振れない状態で0.05秒の 露出をし，次で管球を振らしてトモとしての露出学す る. $\mathrm{kVp}$ や $\mathrm{mA}$ は日常やって居る通りでよい，取枠 へ入れるフイルムはキャビネで充分.

出来上ったフイルムは第 1 図Cの様に黒白の縞目の 外黑線が 1 本写って居る. との黑線の在る方が on 側で，X線管は黒線の処から動き始め暫くしてからス イッチが這入ったのであるから，黒線から縞目の間は 遊びである。

縞目を数えると露出時間が分る，50〜で100あれば 1 秒。 60 〜で 132 あ礼ば 1.1 秒である。

縞の巾が不均等ならばトモの動きが不均等.

編の濃度が不均等ならば $\mathrm{mA}$ 方不均等。

其他卜モの性能を評価する色々な資料が得られる。 又, 是からトモの角度が算出出来る。

$$
\begin{array}{rlrl}
\tan \frac{\theta}{2}=\frac{\frac{A}{2}}{10}=\frac{A}{20} & A & =10 \mathrm{~cm} \text { ならば } \\
\frac{\theta}{2}=\arctan \frac{A}{20} & \theta & =2\left(\arctan \frac{10}{20}\right) \\
\theta=2\left(\arctan \frac{A}{20}\right) & & =2(\arctan 0.5) \\
& =2 \times 26^{\circ} 34^{\prime} \\
& =53^{\circ} 4^{\prime}
\end{array}
$$

\section{肋骨の残影を消す方法}
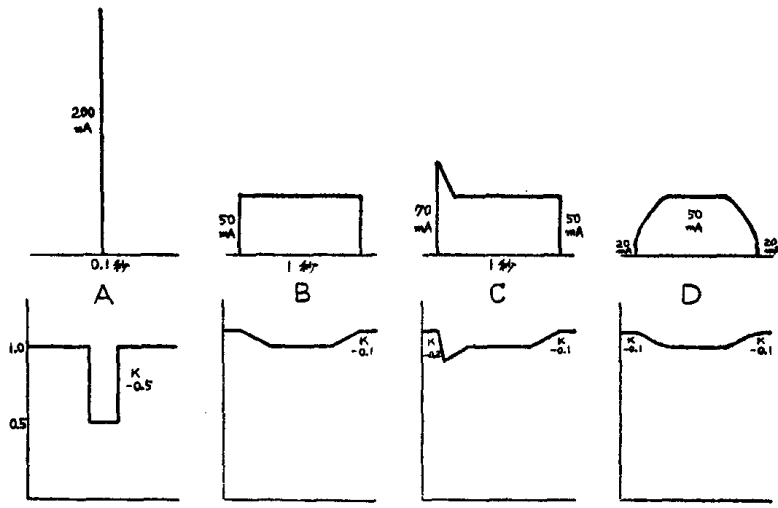

第 2 図 
第 2 図Aは普通の肺写真に於ける肋骨の写り方で, 肺野の濃度 1.0 , 胁骨の呩度 0.5 従って肋骨のコント ラストはー0.5 に写って居るから胁骨が良く見える。 Bはトモの場合で, 肺野の濃度 1.1, 肋骨の濃度 1.0 , 従って肋骨のコントラストは -0.1 に低下し, 且つ両 端にボケを伴うから見えにくくなる，処がストロボ检 查で起動時の速度がのろかったり, 電在変動率が大き くて始めの瞬間文 $\mathrm{mA}$ が多く出たりすると, C図上 段の様な露出が行われるととになる。そうするとボケ の状態は下段の様に始動時に特にコントラストが強く ボケが少なく現われ，肪骨の影が認められることにな る.乙う言う場合には何等かの方法でB図の様な露出 状態に戻せばよい筈である。

更にとの考を発展させてD図上段の様な露出状態即 ち初めと終りの露出を抑えればボケの状態は下段に示 す様になって更に切れ味が良くなるのではないかと考 えられる。

\section{$\mathbf{m A}$ 抑制の方法}

$\mathrm{mA}$ 抑制の方法としては摺動抵抗，インダクタンス， 加熱印加等が考えられるが，私が現在やって居るのは

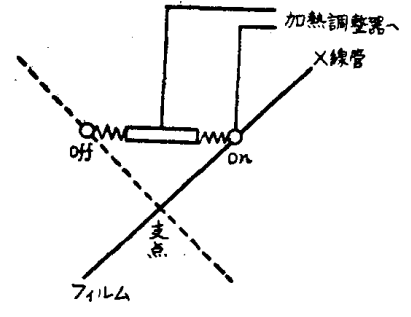

3 図
第3 図に示す替動抵抗 法である。図の様に30 2 位の抵抗置き，そ の中程を紙挾み（クリ ップ）で挾んで配電盤 の加熱調制器へ結ぶ。 紙挾みの幅だけは短絡 された事になる。次に

管球支持棒に接点を取り付けそれを加熱調制器へ結ぶ。 そうすると露出の初めと終りに抵抗力附加されて $\mathrm{mA}$ 計は露出時間中 20-30-50 50 50-30-20 と言 う風に振れる．実際にやって見ると陰極ヒラメントの 熱容量, 抵抗体の温度系数等の関係で仲々思う様には ならない.クリップの位置を加減して調節する。

理論的な事は分らないが，私はこの方法で象に角肋 骨の残影を消すととに成功した。

断風写真も大いに普及したが而肋骨の消えない 写真も屢々見受けるので御参考迄に申述へて置く.

終りに，ストロボに就いて御教示下さった東芝医療 技術課の森さんにお礼电上げ，工作と実験をして下さ った 原，永茾，小河平の諸君に感謝します。

\title{
レントゲン晤室の改造と能率化に就て
}

東京都済生会中央病院放射線科（主任医長 板津三良博士）

川名秀 雄大桃七 郎

（論文受付 昭和30年 1 月20日）

\section{ON THE IMPROVEMENT AND HOW TO ELEVATE EFFICIENCY OF THE DARK ROOM OF THE X-RAY}

\author{
By Director SABORo ItATSU \\ Hideo KaWANa \\ SHICHIRO OMOMO \\ Saiseikai Central Hospital, \\ Tokyo X-Ray Dept.
}

(Article received : Jan. 20, 1955)

Summary

Recently the case of the X-Ray apparatus being applied for medical use is remarkably increasing and larger size of this apparatus has been popularized. Consequently, its adapters is alsos howing an incessant progress. Compared with above facts, an importance of a dark room, which is indispensable for X-ray apparutus is too often neglected. Turning our attention to this fact. We have made the report (as described hereunder) on the rebuilding of a dark room in our hospital. 